\title{
The effect of organic feeding on carcass and meat quality of fattening pigs
}

\author{
J. Urbańczyk ${ }^{1}$, E. Hanczakowska and M. Świątkiewicz \\ National Research Institute of Animal Production, \\ Department of Animal Nutrition and Feed Science \\ 32-083 Balice, Poland
}

\begin{abstract}
The effect of organic feeding on carcass and meat quality was investigated in 160 fattening pigs. All animals received a feed mixture composed of either standard (group I-M1) or organically grown cereals, leguminous seeds and rapeseed cake (experimental groups - M). The pigs additionally received organically cultivated whole-plant maize silage (SM) in groups II and III, and grass silage $(\mathrm{SG})$ in groups IV and V. In groups III and V the animals also received a herb mixture (H). Feeding animals with SM or SG and the herb supplement had an apparent positive effect on carcass quality, meat tenderness and taste. The backfat of the experimental animals contained more PUFA.
\end{abstract}

KEY WORDS: organic feed, pig, carcass, meat quality

\section{INTRODUCTION}

Increasing consumer demands in terms of animal product quality are associated with concern about farm animal welfare and feeding. This has resulted in growing numbers of organic farms (Foster and Lumpkin, 1999). Their goal is to produce higher quality animal products that meet consumer expectations. Organically fed animals must receive roughage feeds, which affect not only the fattening results but also carcass dressing and meat quality (Sandrum et al., 2000). This type of feeding also influences the fatty acid composition of meat fat (Högberg et al., 2003) and its sensory qualities (Danielsen et al., 2000).

The purpose of this experiment was to evaluate the effect of organic feeding on the carcass dressing percentage, meat quality and fatty acid composition of backfat in comparison with traditional feeding.

\footnotetext{
${ }^{1}$ Corresponding author: e-mail: jurban@izoo.krakow.pl
} 


\section{MATERIAL AND METHODS}

The experiment was carried out on 160 fattening pigs originated from Polish Large White $\times$ Polish Landrace sows mated with a Belgian Landrace $\times$ Pietrain boar. The control group was given a limited feed mixture based on soyabean meal (M1). The experimental animals were fed a limited mixture composed of organically grown cereals, legume seeds and rapeseed cake. Both mixture were isoproteinous and isoenergetic. Additionally, group II received, ad libitum, silage from organically cultivated whole maize plants (SM), group III the same silage and a $0.5 \%$ supplement of a herb mixture. In group IV, the maize silage was substituted by grass silage (SG), and group $\mathrm{V}$ received grass silage and the herb mixture. The animals were fed twice a day. After both feedings the appropriate silages were given to the experimental animals (groups II-V) and refusals was weighed before each feeding.

The animals were kept in the experiment from about 30 to $114 \mathrm{~kg}$ of body weight. The animals were then slaughtered and dissected. Samples of loin were taken for chemical (AOAC, 1990) and sensory analyses. The fatty acid profile of backfat was analysed using a Philips 4500 gas chromatograph. Statistical one-way analysis was carried out with the STATISTICA 5.1 software package.

\section{RESULTS}

Table 1. Meat and fat quality

\begin{tabular}{|c|c|c|c|c|c|c|}
\hline \multirow[b]{2}{*}{ Item } & \multicolumn{5}{|c|}{ Feeding groups } & \multirow[b]{2}{*}{ SEM } \\
\hline & $\begin{array}{c}\mathrm{I} \\
\mathrm{M} 1\end{array}$ & $\underset{\mathrm{M}+\mathrm{SM}}{\mathrm{II}}$ & $\begin{array}{c}\mathrm{III} \\
\mathrm{M}+\mathrm{SM}+\mathrm{H}\end{array}$ & $\begin{array}{c}\mathrm{IV} \\
\mathrm{M}+\mathrm{SG}\end{array}$ & $\frac{\mathrm{V}}{\mathrm{M}+\mathrm{SG}+\mathrm{H}}$ & \\
\hline Cold dressing yield, $\%$ & $79.8^{\mathrm{B}}$ & $78.7^{\mathrm{A}}$ & $78.7^{\mathrm{A}}$ & $78.6^{\mathrm{A}}$ & $78.5^{\mathrm{A}}$ & 0.13 \\
\hline Meat of primal cuts, $\mathrm{kg}$ & $25.53^{\mathrm{aA}}$ & $25.76^{\mathrm{aA}}$ & $27.38^{\mathrm{bB}}$ & $27.32^{\mathrm{bB}}$ & $26.25^{\mathrm{aAB}}$ & 0.19 \\
\hline Meat content in carcass, $\%$ & $56.5^{\mathrm{aA}}$ & $58.0^{\mathrm{aAB}}$ & $58.6^{\mathrm{abAB}}$ & $61.13^{\mathrm{cB}}$ & $60.85^{\mathrm{bcB}}$ & 0.40 \\
\hline Backfat thickness, cm & $2.57^{\mathrm{cB}}$ & $2.39^{\mathrm{bAB}}$ & $2.31^{\mathrm{abA}}$ & $2.18^{\mathrm{aA}}$ & $2.13^{\mathrm{aA}}$ & 0.03 \\
\hline Water holding capacity, $\%$ & $22.34^{\mathrm{b}}$ & $20.70^{\mathrm{a}}$ & $22.20^{\mathrm{b}}$ & $21.51^{\mathrm{ab}}$ & $22.34^{\mathrm{b}}$ & 0.21 \\
\hline \multicolumn{7}{|l|}{ Meat colour, Hunter } \\
\hline lightness (L) & $46.57^{b}$ & $44.37^{\mathrm{a}}$ & $45.57^{\mathrm{ab}}$ & $44.29^{a}$ & $46.57^{b}$ & 0.25 \\
\hline redness (a) & $12.90^{\mathrm{b}}$ & $12.54^{\mathrm{ab}}$ & $12.27^{\mathrm{a}}$ & $12.38^{\mathrm{a}}$ & $12.9^{b}$ & 0.06 \\
\hline yellowness (b) & $2.05^{\mathrm{A}}$ & $2.08^{\mathrm{A}}$ & $2.17^{\mathrm{A}}$ & $2.39^{\mathrm{A}}$ & $3.05^{\mathrm{B}}$ & 0.07 \\
\hline \multicolumn{7}{|l|}{$\begin{array}{l}\text { Chemical composition of } \\
\text { meat, } \%\end{array}$} \\
\hline dry matter & $25.06^{b}$ & $24.77^{\mathrm{ab}}$ & $24.69^{\mathrm{ab}}$ & $24.40^{\mathrm{a}}$ & $24.61^{\mathrm{ab}}$ & 1.12 \\
\hline crude protein & $22.85^{\mathrm{ab}}$ & $23.14^{b}$ & $22.76^{\mathrm{ab}}$ & $22.59^{\mathrm{a}}$ & $22.83^{\mathrm{ab}}$ & 0.97 \\
\hline crude fat & 1.61 & 1.40 & 1.69 & 1.37 & 1.38 & 0.06 \\
\hline Odour & 4.66 & 4.68 & 4.74 & 4.66 & 4.72 & 0.02 \\
\hline Taste & $4.35^{\mathrm{aA}}$ & $4.39^{\mathrm{aA}}$ & $4.63^{\mathrm{cB}}$ & $4.41^{\mathrm{abA}}$ & $4.54^{\mathrm{bcAB}}$ & 0.02 \\
\hline Tenderness & $4.36^{\mathrm{aAB}}$ & $4.26^{\mathrm{aA}}$ & $4.51^{\mathrm{bB}}$ & $4.30^{\mathrm{aA}}$ & $4.37^{\mathrm{aAB}}$ & 0.02 \\
\hline Juiciness & 4.31 & 4.26 & 4.44 & 4.26 & 4.79 & 0.09 \\
\hline
\end{tabular}

$\overline{\mathrm{a}, \mathrm{b}, \mathrm{c}}-\mathrm{P} \leq 0.05,{ }^{\mathrm{A}, \mathrm{B}}-\mathrm{P} \leq 0.01$ 
Silage supplements lowered carcass dressing yield when compared with the control group $(\mathrm{P} \leq 0.01)$. On the other hand, the experimental animals, in particular, those receiving $\mathrm{SG}$, deposited more meat and had thinner backfat (Table 1). In this case the differences when compared with the controls were highly significant. Organic feeding with a herb supplement had no distinct effect on water holding capacity or colour of meat, but without these supplements the indices were better than in the control group.

Table 2. Fatty acid composition of backfat

\begin{tabular}{lcccccc}
\hline & \multicolumn{5}{c}{ Feeding groups } & \\
\cline { 2 - 5 } Item & $\mathrm{I}$ & $\mathrm{II}$ & $\mathrm{III}$ & $\mathrm{IV}$ & $\mathrm{V}$ & \multirow{2}{*}{$\mathrm{SEM}$} \\
& $\mathrm{M} 1$ & $\mathrm{M}+\mathrm{SM}$ & $\mathrm{M}+\mathrm{SM}+\mathrm{H}$ & $\mathrm{M}+\mathrm{SG}$ & $\mathrm{M}+\mathrm{SG}+\mathrm{H}$ & \\
\hline SFA & $44.12^{\mathrm{cB}}$ & $41.74^{\mathrm{bA}}$ & $40.72^{\mathrm{abA}}$ & $39.41^{\mathrm{aA}}$ & $40.65^{\mathrm{abA}}$ & 0.34 \\
UFA & $55.87^{\mathrm{aA}}$ & $58.26^{\mathrm{bB}}$ & $59.28^{\mathrm{bcB}}$ & $60.28^{\mathrm{cB}}$ & $59.35^{\mathrm{bcB}}$ & 0.34 \\
MUFA & $43.10^{\mathrm{abAB}}$ & $42.85^{\mathrm{aA}}$ & $43.91^{\mathrm{abcAB}}$ & $44.98^{\mathrm{cB}}$ & $44.38^{\mathrm{bcAB}}$ & 0.24 \\
PUFA & $12.77^{\mathrm{A}}$ & $15.41^{\mathrm{B}}$ & $15.37^{\mathrm{B}}$ & $15.60^{\mathrm{B}}$ & $14.97^{\mathrm{B}}$ & 0.23 \\
PUFA - n-6 & $10.67^{\mathrm{A}}$ & $12.77^{\mathrm{B}}$ & $12.78^{\mathrm{B}}$ & $12.96^{\mathrm{B}}$ & $12.36^{\mathrm{B}}$ & 0.21 \\
PUFA-n-3 & $0.47^{\mathrm{A}}$ & $0.75^{\mathrm{B}}$ & $0.77^{\mathrm{B}}$ & $0.80^{\mathrm{B}}$ & $0.74^{\mathrm{B}}$ & 0.02 \\
MUFA / SFA & $0.98^{\mathrm{A}}$ & $1.03^{\mathrm{AB}}$ & $1.08^{\mathrm{BC}}$ & $1.14^{\mathrm{C}}$ & $1.10^{\mathrm{BC}}$ & 0.01 \\
PUFA / SFA & $0.29^{\mathrm{A}}$ & $0.37^{\mathrm{B}}$ & $0.38^{\mathrm{B}}$ & $0.40^{\mathrm{B}}$ & $0.37^{\mathrm{B}}$ & 0.01 \\
\hline
\end{tabular}

a,b,c $-\mathrm{P} \leq 0.05, \mathrm{~A}, \mathrm{~B}-\mathrm{P} \leq 0.01$

The herb mixture improved the results of sensory analysis of meat, especially its taste and tenderness. The neck backfat of the experimental animals contained significantly less saturated and more n-6 and n-3 unsaturated fatty acids (Table 2).

\section{DISCUSSION}

The available literature data concerning the effect of organic feeding on pig carcass and meat quality are inconsistent. This is due mainly to the different composition of feed mixtures used in particular experiments. In contrast to the results obtained in the presented experiment, Soudrum et al. (2000) found a lower meat and higher fat content in the carcasses of pigs fed with a mixture containing barley, wheat, field bean and potato protein. On the other hand, Danielsen et al. (2000), when giving a mixture with red clover and red clover silage found lower weight gains and higher meat content in the carcass, which was due to the lower energy concentration in feed. It seems that in our experiment the higher meat content in the carcasses of organically fed pigs was also the result of their lower daily body weight gains. The meat of experimental pigs was more tender and tasty. After grazing, a lower carcass dressing was also found (Gustafson and Stern, 2003). Högberg et al. (2003) found a favourable effect of organic feeding on the fatty acid composition of meat fat, similarly to that found in the present experiment. 


\section{CONCLUSIONS}

Organic feeding of fattening pigs with maize or grass silages and a herb mixture increased the meat content of the carcass but lowered the carcass dressing yield. This type of feeding also improved meat quality and increased the unsaturated fatty acid profile in backfat.

\section{REFERENCES}

AOAC, 1990. Official Methods of Analysis, Association of Official Analytical Chemists. $15^{\text {th }}$ Edition. Arlington, VA

Danielsen V., Hansen L.L., Moller F., Bejerholm C., Nielsen S., 2000. Production results and sensory meat quality of pigs fed different amounts of concentrate and ad libitum clover-grass or clover-grass silage. Ecological Animal Husbandry in the Nordic Countries. DARCOF Report $2,79-86$

Foster C., Lampkin N., 1999. Organic Farming in Europe: Economics and Policy, Part 3. Hohenheim

Gustafson G., Stern S., 2003. Two strategies for meeting energy demands of growing pigs at pasture. Livest. Prod. Sci. 80, 167-174

Högberg A., Pickova J., Andersson K., Lundström K., 2003. Fatty acid composition and tocopherol content of muscle in pigs fed organic and conventional feed with different n6/n3 ratios, respectively. Food Chem. 80, 177-186

Sundrum A., Butfering L., Henning M., Hoppenbrock K.H., 2000. Effects of on-farm diets for organic pig production on performance and carcass quality. J. Anim. Sci. 78, 5, 1199-1205

\section{STRESZCZENIE}

\section{Wpływ ekologicznego żywienia tuczników na jakość tuszy i mięsa}

W doświadczeniu przeprowadzonym na 160 tucznikach badano wpływ żywienia ekologicznego na jakość tusz i mięsa. Wszystkie zwierzęta żywiono mieszanką pełnoporcjową, w grupie kontrolnej standardową - M1, a w doświadczalnych złożoną z uprawianych ekologicznie zbóż, nasion roślin strączkowych oraz makuchu rzepakowego (M). Ponadto w grupie II i III zwierzęta otrzymywały kiszonkę z całych roślin kukurydzy uprawianej ekologicznie - SM, w IV i V kiszonkę z traw - SG, a tuczniki z grup III i V dodatek ziół - H. Ekologiczne żywienie tuczników dawkami z udziałem SM lub SG oraz z dodatkiem ziół wpłynęło korzystnie na jakość tuszy, kruchość i smak mięsa. Słonina tuczników doświadczalnych zawierała więcej kwasów PUFA. 